УДК 338.330.141

DOI 10.35433/ISSN2410-3748-2020-1(26)-5

JEL Classification: R 13, R 32, A13

Микитенко Вікторія

д.е.н., проф.,

головний наук. спів. відділу методології сталого розвитку, ДУ «Інститут економіки природокористування та сталого розвитку НАН України», м. Київ, Україна

ORCID 0000-0002-8212-9777

\title{
МЕХАНІЗМИ РЕАЛІЗАЦІЇ ІНТЕГРАЛЬНОЇ ПРОСТОРОВОЇ МОДЕЛІ УПРАВЛІННЯ ПРИРОДНО-РЕСУРСНИМИ АКТИВАМИ В УМОВАХ СУСПІЛЬНО-ПОЛІТИЧНОЇ ТА ЕКОНОМІЧНОЇ КРИЗИ І ЗАГРОЗ НАЦІОНАЛЬНІЙ БЕЗПЕЦІ
}

\footnotetext{
У статті сформовано, розмежовано та структуровано комплекси організачійно-економічних механізмів реалізації дії за трьома етапами імплементації інтегральної просторової моделі управління територіальними природно-ресурсними активами (ініціація, консолідація, інкорпорація) в умовах тотального нарощення загроз і ризиків національній безпеці. До складу системоутворюючих комплексів включено п'ять блоків фінансово-економічних, нормативно-правових, інформаційнометодичних, системно-універсальних та публічно-приватного партнерства підмеханізми цілеорієнтованого впливу на пріоритетні об'єкти просторового управління. Доведено, що одночасна реалізачія їхньої дії за кожним із трьох етапів імплементації просторової моделі забезпечує синхронний перебіг параболічних подій із: інтенсифікації процесів видобутку, освоєння, використання, трансформації та нарощення природно-ресурсного потениііалу територій; раціоналізації обміну перерозподілу природно-ресурсних активів територіальних природно-господарських округів; досягнення результативності просторового управління. Вказане досягається, навіть в умовах ресурсних обмежень, масштабного нарощення ризиків і криз, які, наразі, мають місие в державі, за рахунок конституювання і введення у практику складно-організованої інтегральної просторової моделі управління територіальними природно-ресурсними активами держави. Автором запропоновано до використання у практиці господарювання структурно-логічну схему групування організаційноекономічних механізмів, в межах якої розроблено й обтрунтовано універсальний, для трьох етапів імплементації просторової моделі в Украӥні, алгоритм, за яким безперервно має відбуватися їх групування, добір та переформатування за кожним етапом у замкненому цииклі виконання управлінських, організаційно-економічних, техніко-економічних, прогнозно-аналітичних та економетричних процедур. Дотримання процедур за ичим алгоритмом забезпечує єдність множини елементів
}

(C) Микитенко Вікторія 
інтегрованої моделі просторового управління, кожен із яких відіграє певну специифічну роль, невід’ємну для реалізації ичільових функціоналів варіативного механізму просторового управління природно-ресурсними активам.

Ключові слова: просторове управління природно-ресурсними активами,

організаційно-економічні механізми, інтегральна просторова модель управління, замкнений циикл, групування організаџійно-економічних механізмів, етапи імплементації інтегральної просторової моделі.

\title{
MECHANISMS FOR IMPLEMENTING THE INTEGRATED SPATIAL MODEL OF NATURAL RESOURCE ASSET MANAGEMENT IN THE CONTEXT OF SOCIO- POLITICAL AND ECONOMIC CRISIS AND THREATS TO NATIONAL SECURITY
}

\begin{abstract}
In the article complexes of organizational and economic mechanisms of implementation of action are formed, delineated and structured in three stages of implementation of the integrated spatial model of management of territorial natural resources assets in the conditions of total increase of threats and risks to national security. The systemforming complexes include five blocks of financial-economic, regulatory, informational, methodological, system-universal and public-private partnerships, sub-mechanisms of targeted influence on priority spatial management objects.

It is proved that simultaneous realization of their action at each of the three stages of implementation spatial model provides synchronous flow of parabolic events from: intensification of processes of extraction, development, utilization and increase of natural resource potential of territories; rationalization of exchange of redistribution of natural resource economic assets of territories spatial management. This is achieved, even in the context of resource constraints, the large-scale increase in risks and crises that are currently taking place through the constitution and implementation of a complex, integrated spatial model of managing the state's territorial natural resources.

The author proposes to use in the practice of management structural and logical scheme of grouping of organizational and economic mechanisms, within which a universal is developed and substantiated, for three stages of implementation of the spatial model in Ukraine, an algorithm according to which their grouping, selection and reformatting should be continuously carried out in each closed loop, organizational, economic, technical and economic, forecasting and econometric procedures. Adherence to the procedures of this algorithm ensures the unity of many elements of the integrated spatial management model, each of which plays a specific role, indispensable for the realization of the targeted functional of the spatial asset management mechanism.

Keywords: spatial management of natural resource assets, organizational and economic mechanisms, integrated spatial model of management, closed loop, grouping of organizational and economic mechanisms, stages of implementation of the integrated spatial model.
\end{abstract}

Постановка проблеми в загальному вигляді. Зведення, добір та групування механізмів реалізації дії різної природи, зазвичай, i, як правило, обмежується простим їх підрахунком по досліджуваній сукупності та розмежуванням за пріоритетністю щодо використання. Але, 
вихідна інформація щодо групування i розмежування як важелів i регуляторів, так і механізмів, загалом, на певній стадії їх вивчення та застосування обов'язково слід впорядкувати, систематизувати, поділивши системоутворюючі регулятори та важелі цілеорієнтованого впливу на групи за найбільш суттєвими ознаками у контексті розв'язання тієї чи іншої проблеми. Особливо це $є$ нагальним для тих умов, в яких функціонує, наразі, національна соціально-економічна система. При цьому, для пріоритетних на сучасному етапі розвитку останньої, організаційноекономічних механізмів, їх групування має відповідати пріоритетам на кожному з етапів імплементації (ініціація, консолідація, інкорпорація) національної системи просторового управління територіальними природно-ресурсними активами. Вказане досягається за допомогою використання статистичних, логістичних, атрибутивних чи вторинних згрупувань - за результатами врахування вирішального аспекту щодо зведення найбільш дієвих, на певному етапі впровадження у практику господарювання, механізмів реалізації інтегральної просторової моделі управління територіальними природно-ресурсними активами в Україні.

Аналіз попередніх досліджень та публікацій. Теоретичним, методологічним, методичним i прикладним аспектами вирішення багатогранних проблем щодо формування та запровадження у практику сучасних механізмів реалізації інтегральної просторової моделі управління територіальними природно-ресурсними активами в Україні присвячено наукові праці О. Алимова, I. Бистрякова, I. Драган, Д. Клинового, I. Лицура, М. Хвесика та інших вчених-економістів [1-4]. Проте, віддаючи належне теоретичній, методологічній та практичній цінності попередніх здобутків, існує гостра потреба в проведені системного дослідження проблеми щодо визначення i врахування особливостей групування організаційно-економічних механізмів у контексті реалізації інтегральної 
просторової моделі управління природно-ресурсними активами в умовах суспільно-політичної та економічної кризи і загроз національній безпеці.

Формування цілей сmammi: є розробка методичних і прикладних основ групування організаційно-економічних механізмів задля реалізації інтегральної просторової моделі управління природно-ресурсними активами в умовах, які, наразі, існують в державі, при нарощенні суспільно-політичної та економічної кризи і масштабів загроз національній безпеці.

Виклад основного матеріалу досліджсенн. На авторське переконання, ключовими, 3 огляду на нагальність вирішення цієї проблематики з урахуванням нарощення не лише суспільно-політичних, а й біотехнологічних, медико-соціальних та медико-генетичних загроз i ризиків сучасному українському державотворенню, загалом, як i національній економіці, зокрема, - $\epsilon$, у перше чергу, сукупність організаційно-економічних механізмів реалізації й адаптації інтегральної просторової моделі управління територіальними природно-ресурсними активами [5]. Адже, процедури врахування особливостей групування організаційно-економічних механізмів реалізації інтегральної просторової моделі управління територіальними природно-ресурсними активами України - являють собою розподіл сукупності організаційно-економічних важелів та регуляторів на однорідні типові групи за найбільш суттєвими для них ознаками, на певному етапі розвитку національної соціальноекономічної системи, у відповідності з алгоритмом імплементації системи просторового управління. Вказане виконується 3 метою всебічної характеристики їх стану, спрямування загальноекономічного розвитку, а також реалізації, удосконалення та обгрунтування пріоритетних напрямів імовірної трансформації взаємозв'язків i взаємозалежностей задля нагального запровадження у практику сучасної просторової системи управління природно-ресурсними активами в умовах нарощення 
глобальних загроз різної природи і суспільних, соціальних та фінансовоекономічних реальних ризиків, які, у своїй сукупності є, наразі, викликами національній безпеці.

3 цього, зазначимо: по-перше: пріоритетними для опрацювання у контексті розв'язання поставленого науково-прикладного завдання - $€$ організаційно-економічні механізми, які мають надзвичайну вагомість i специфічність характеру впливу на забезпечення стійкості економічної системи та результативності просторового управління. Наступними за вагомістю - $є$ інституційні механізми, i, надалі, відповідно, екологічні. А, по-друге: на І-му етапі реалізації інтегральної просторової моделі управління природно-ресурсними активами (ініціації) - доцільним для застосування є наступний комплекс важелів та регуляторів організаційноекономічного впливу [6], розмежований за п’ятьма такими основами (рис. 1), a came:

- цілеорієнтованого впливу на процеси реалізації інтегрованої моделі просторового управління природно-ресурсними активами, які, перш за все, слід систематизувати та розмежувати за визначеними для кожної території, інкорпорованої до певного територіального природно-господарського утворення, пріоритетами. Вказане передбачає формування з їхнього складу та запровадження у практику господарювання такого комплексу організаційно-економічних механізмів (а, в їх межах відповідних важелі та регуляторів), який забезпечить пошук, обгрунтування i реалізацію ефективних рішень щодо забезпечення достатнього рівня як результативності управління природно-ресурсними активами, так економічної безпеки та сталого розвитку територіальних природногосподарських утворень, у цілому, і окремої території, зокрема; інноваційний характер просторової системи, що передбачає перехід на 


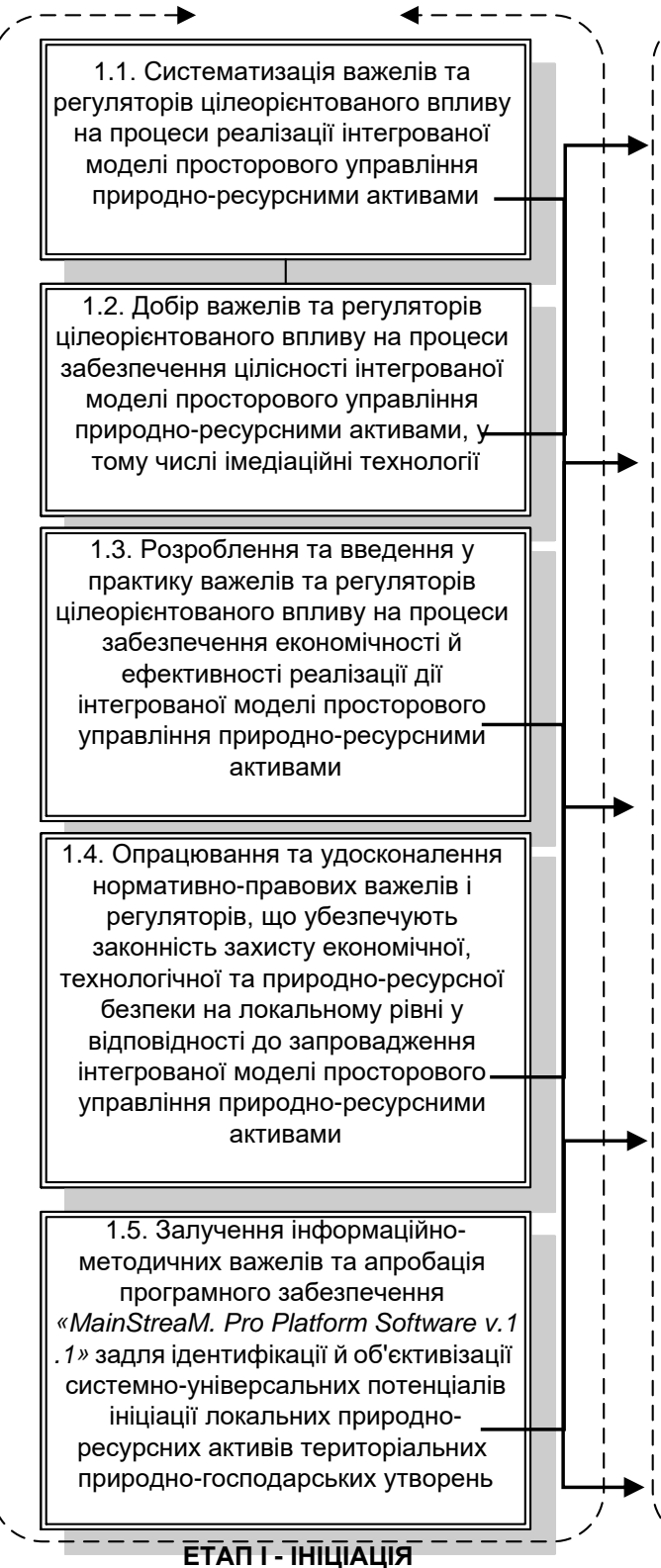

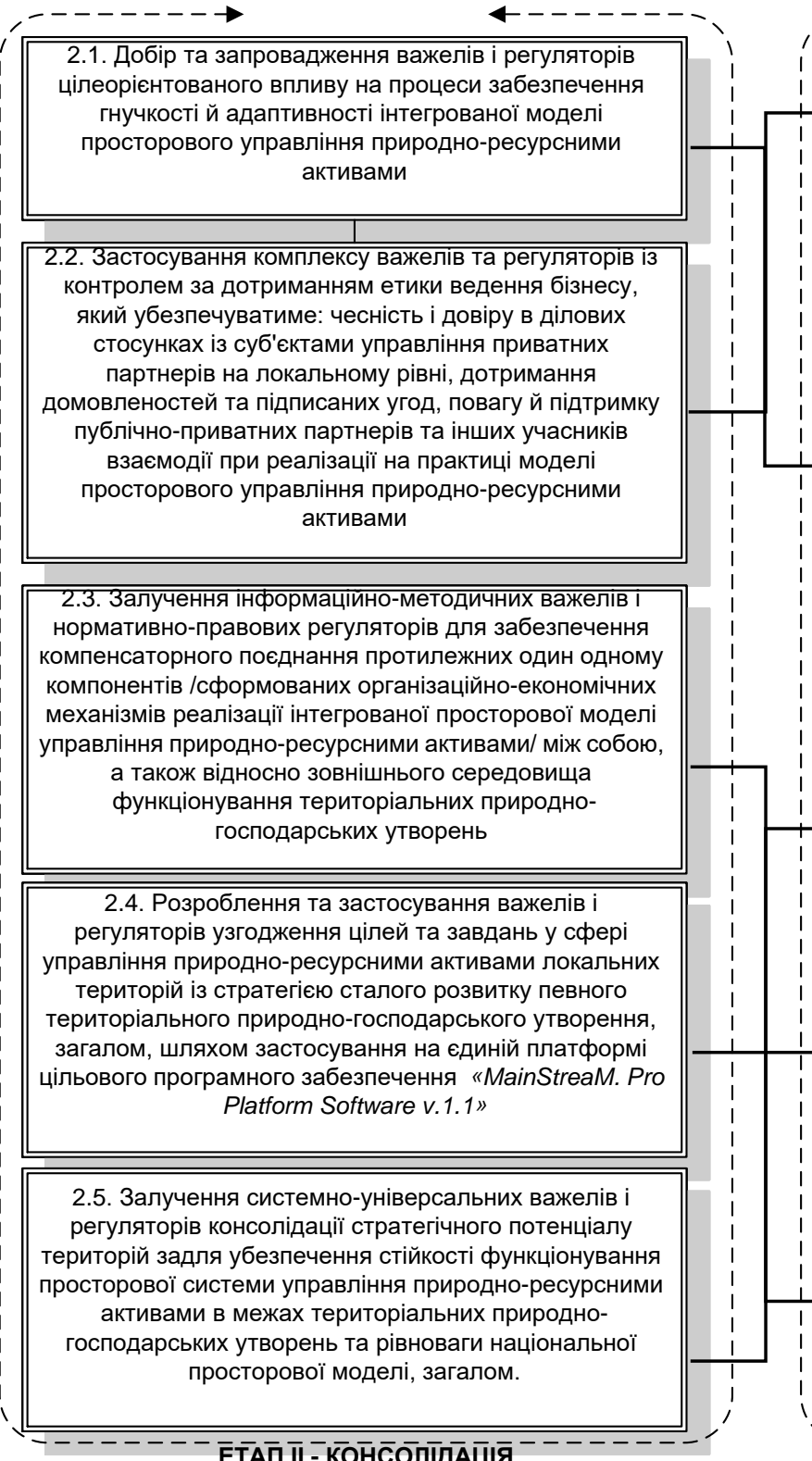

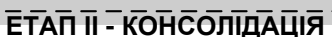

$----\rightarrow$

$4------$

3.1. Розроблення та застосування нормативно-

авових важелів і регуляторів задля інкорпора локальних підсистем просторової моделі управління природно-ресурсними активами територіальних природно-господарських утворень до загальної національної системи просторового управління.

3.2. Залучення системно-універсальних важелів регуляторів забезпечення комплексності, системності та гнучкості у прийнятті управлінських рішень стратегічного, оперативного та аналітичного спрямування за пріоритетами функціонування територіальни природно-

управпіння природно-ресурсними активами.

3.3 Розроблення та використання дієвих фінансово-економічних регуляторів задля забезпечення результативності просторового природно-ресурсним аиивами з урахуванням масштабів потенціалу сталого розвитку територій тӓхніх трансформацій в умовах глобальних загроз і внутрішніх ризиків сталому господарюванню

3.4. Застосування удосконалених інформаційнометодичних важелів задля узгодження

стратегічного та поточного планування шляхом застосування єдиних методичних підходів 1 стандартів, а також і аналітичних процедур, опрацьованих за єдиним критерієм оцінкипрогнозування результативності просторового управління природно-ресурсними активами

3.5. Удосконалення системно-універсальних важелів і регуляторів перманентного контролінгу на усіх етапах просторового управління природноресурсними активами, застосування об'єктивних стимулів до учасників публічно-приватного партнерства та тотальне охоплення загальною інформаційно-комунікаційною платформою діяпьності з використання ПРА в державі.

\section{Рис. 1 Групування організаційно-економічних механізмів реалізації інтегральної просторової моделі управління територіальними природно-} ресурсними активами за етапами її імплементації

(C) Микитенко Вікторія 
високі стандарти діяльності у сфері природокористування та прагнення до активізації впровадження нововведень, вимагатиме здійснення добору найбільш дієвих важелів та регуляторів цілеорієнтованого впливу на забезпечення цілісності самої інтегрованої моделі;

- забезпечення єдності множини елементів інтегрованої моделі просторового управління, кожен із яких відіграє свою конкретну роль, невід’ємну для цільових функціоналів варіативного механізму просторового управління природно-ресурсними активами, обумовлюватиме необхідність обов'язкового розроблення i введення важелів, які забезпечать економічність та ефективність реалізації дії просторової системи, у першу чергу, на локальному рівні. Вказане передбачає, що витрати на організацію діяльності просторової системи повинні, з одного боку, забезпечувати їі ефективне функціонування, а 3 іншого - відповідати фінансовим можливостям певного територіального природно-господарського утворення, загалом, як i певної території, зокрема;

опрацювання та удосконалення нормативно-правових важелів і регуляторів, що дозволяють забезпечити законність захисту економічної, технологічної, та природно-ресурсної безпеки на локальному рівні шляхом подальшого розвитку державного законодавства у сфері місцевого управління активами, малого й середнього бізнесу, інформатизації i захисту інформації, приватної охоронної діяльності та інших нормативних актів із безпеки, затверджених органами державного управління в межах їх компетенції, із застосуванням всіх дозволених методів виявлення i припинення правопорушень як в межах системи регіонального й місцевого управління, так і провадження підприємницької діяльності;

залучення інформаційно-методичних важелів та нормативноправових регуляторів для забезпечення компенсаторного поєднання протилежних один одному компонентів, сформованих організаційно- 
економічних механізмів реалізації інтегрованої просторової моделі управління природно-ресурсними активами, між собою, а також відносно зовнішнього середовища функціонування територіальних природногосподарських утворень;

- залучення інформаційно-методичних важелів та апробація цільового програмного забезпечення «MainStreaM. Pro Platform Software v.1.1» платформного типу задля ідентифікації наявного природноресурсного потенціалу й об’єктивізації системно-універсальних потенціалів ініціації локальних природно-ресурсних активів територіальних природно-господарських утворень.

Вказаний перелік важелів та регуляторів, що й формують певний комплекс механізмів, за етапом ініціації, дозволив згрупувати організаційно-економічні механізми і за іншими етапами алгоритму імплементації інтегральної просторової моделі. Так, зокрема, за етапом II консолідації, визнано доцільним для застосування й наступні груп важелів та регуляторів:

- цілеорієнтовано впливу на процеси забезпечення гнучкості й адаптивності інтегрованої моделі просторового управління природноресурсними активами. Вони убезпечують відповідність цього організаційно-економічного механізму сучасному мінливому зовнішньому та внутрішньому середовищу господарювання як в межах певних територій, так і у метапросторі нашої держави. Оскільки, практично кожна територія стоїть перед необхідністю адаптації до зовнішнього середовища i, саме тому, вона потребує проведення гнучкої політики у сфері природокористування відносно суспільно-політичних, мікро- і макроекономічних процесів;

специфічного типу, із контролем за дотриманням: етики бізнесу, який передбачає чесність i довіру в ділових стосунках між партнерами різного рівня, домовленостей та підписаних угод, поваги до 
партнерів та інших учасників взаємодії. Оскільки, вказане лягає в основу довготривалих відносин і забезпечення результативності просторового управління.

Поряд із цими двома визначальними групами системоутворюючих важелів, найбільш дієвими $є$ й наступні комплекси регулятивів: 1) специфічних системоутворюючих важелів і регуляторів, що убезпечують узгодження цілей та завдань у сфері управління природно-ресурсними активами слабких і не стійких локальних територій із стратегією сталого розвитку певного територіального природно-господарського утворення, загалом, шляхом застосування на єдиній платформі оригінального цільового програмного забезпечення «MainStreaM. Pro Platform Software v.1.1»; 2) системно-універсальних важелів і регуляторів консолідації стратегічного потенціалу територій, загалом, задля убезпечення стійкості й адаптивності функціонування новоствореної або ж удосконаленого формату просторової системи управління природно-ресурсними активами в межах територіальних природно-господарських утворень та рівноваги національної просторової моделі управління, у цілому.

Вказані групи розбудови організаційно-економічних механізмів, як за етапом ініціації, так і за етапом консолідації, можуть змінювати свої назви протягом часу, або ж мати й однакові (за потребою, проте відмінні за складом). Проте, сутність їх та цільові функціонали мають бути незмінними. Крім загальних особливостей, використаних на етапах ініціації та консолідації, для групування організаційно-економічних механізмів реалізації інтегральної просторової моделі управління територіальними природно-ресурсними активами, для третього етапу інкорпорації - враховано, дещо, інші принципи групування системоутворюючих важелів і регуляторів. А, саме ті, що дозволяють перманентно коригувати цілі та завдання, уточнювати пріоритети на певний період упередження 3 урахуванням накопичених $\mathrm{i}$ набутих 
масштабів потенціалу сталого розвитку, а також викликів, загроз і ризиків різного рівня. Так, зокрема, на III-му етапі - інкорпорації - пропонуються для використання:

нормативно-правові важелі та регулятори, що убезпечують інкорпорацію локальних підсистем просторової моделі управління природно-ресурсними активами територіальних природно-господарських утворень до загальної національної системи просторового управління;

системно-універсальні важелі та регулятори забезпечення комплексності, системності і гнучкості у прийнятті управлінських рішень стратегічного, оперативного та аналітичного спрямування за пріоритетами функціонування територіальних природно-господарських утворень за просторовою моделлю управління природно-ресурсними активами;

дієві фінансово-економічні регулятори задля забезпечення результативності просторового природно-ресурсними активами 3 урахуванням масштабів потенціалу сталого розвитку територій та їхніх трансформацій при інкорпорації до територіальних природногосподарських утворень, що відбувається в умовах глобальних загроз різної природи і внутрішніх ризиків сталому господарюванню;

інформаційно-методичні важелі задля узгодження стратегічного та поточного планування шляхом застосування єдиних методичних підходів і стандартів, а також i аналітичних процедур, опрацьованих за єдиним критерієм зустрічної оцінки-прогнозування результативності просторового управління природно-ресурсними активами;

удосконалені системно-універсальні важелі та регулятори перманентного контролінгу на усіх етапах просторового управління природно-ресурсними активами, застосування об'єктивних стимулів до учасників публічно-приватного партнерства та тотальне охоплення загальною інформаційно-комунікаційною платформою діяльності 3 використання природно-ресурсних активів в державі. 
Відтак, визнаємо, що при визначені та врахуванні особливостей групування організаційно-економічних механізмів реалізації інтегральної просторової моделі управління територіальними природно-ресурсними активами за трьома етапами іiі імплементації, які узгоджуються 3 відповідними етапами розбудови в Україні обмеженої кількості територіальних природно-господарських округів [7], передбачалось вирішити та вирішено такі завдання: а) вибір групувальної ознаки та таких відзнак, які надають інформацію про фінансово-економічні потреби для забезпечення результативності управління природно-ресурсними активами територій; б) визначення кількості груп за величинами термінів певного (одного з трьох) інтервалу імплементації; в) встановлення переліку ознак, якими повинні характеризуватись виділені групи механізмів стосовно конкретного групування; г) складання макетів таблиць, де представляються результати групування відповідного типу організаційноекономічних механізмів. I, поряд із вказаними вище, ще й організаційні параметри розвиненості місцевих та регіональних об'єктів управління природокористуванням, які дозволять, надалі, здійснити переформатування організаційної структури управління громад i територіальних природно-господарських утворень, навіть при обмеженості ресурсів, що i обумовить можливість створення нових підрозділів, удосконалити взаємозв'язки між елементами просторової системи управління, які відповідатимуть за виконання цільових функцій кожною 3 п’яти їі базових підсистем.

Тож, як визнано автором, групування й добір організаційно-економічних механізмів має відбуватися безперервно за кожним із трьох етапів імплементації інтегральної просторової моделі управління територіальними природно-ресурсними активами у замкненому циклі виконання управлінських, організаційно-економічних, проектних та економетричних процедур, що можна представити у вигляді рис. 2. I, 
одним iз ключових елементів реалізації організаційно-економічних процедур, приведених на рис. 2, стає розроблення та використання у практиці просторового управління специфічного прикладного інструментарію - a, саме, методичного підходу до групування організаційно-економічних механізмів реалізації інтегральної просторової моделі управління територіальними природно-ресурсними активами, який є взаємопов’ язаним із застосуванням цільового програмного забезпечення платформного типу.

Для чіткого визначення об’єктів впливу і відповідних корелянтів та їх повноважень, локалізації наявних ресурсів, резервів та можливостей і їхнього спрямування за пріоритетами раціонального освоєння та використання природно-ресурсних активів із автоматизацією процесів інформаційного забезпечення та моделювання імовірних трансформацій в умовах нарощення загроз і ризиків національній безпеці, постає нагальна потреба у розробці та формалізації схеми реалізації на практиці методичного підходу щодо групування організаційно-економічних механізмів, яка передбачає замкненість циклу виконання поставленого завдання. 3 цього, вбачаємо за необхідність зазначити таке: методичний підхід щодо групування організаційно-економічних механізмів реалізації інтегральної просторової моделі управління територіальними природноресурсними активами України (процедури реалізації інструментарію- на рис. 3) має специфічну відмінність від пропонованого авторами у [8] методичного підходу, оскільки, має бути замкненим [5].

Специфічність прикладного інструментарію полягає ще й у виконанні процедур добору, розмежування і комбінування, окремо, за кожним із трьох етапів імплементації просторової системи управління, найбільш дієвих комплексів важелів i регуляторів організаційноекономічного впливу. Вказане вимагає використання, поряд iз 


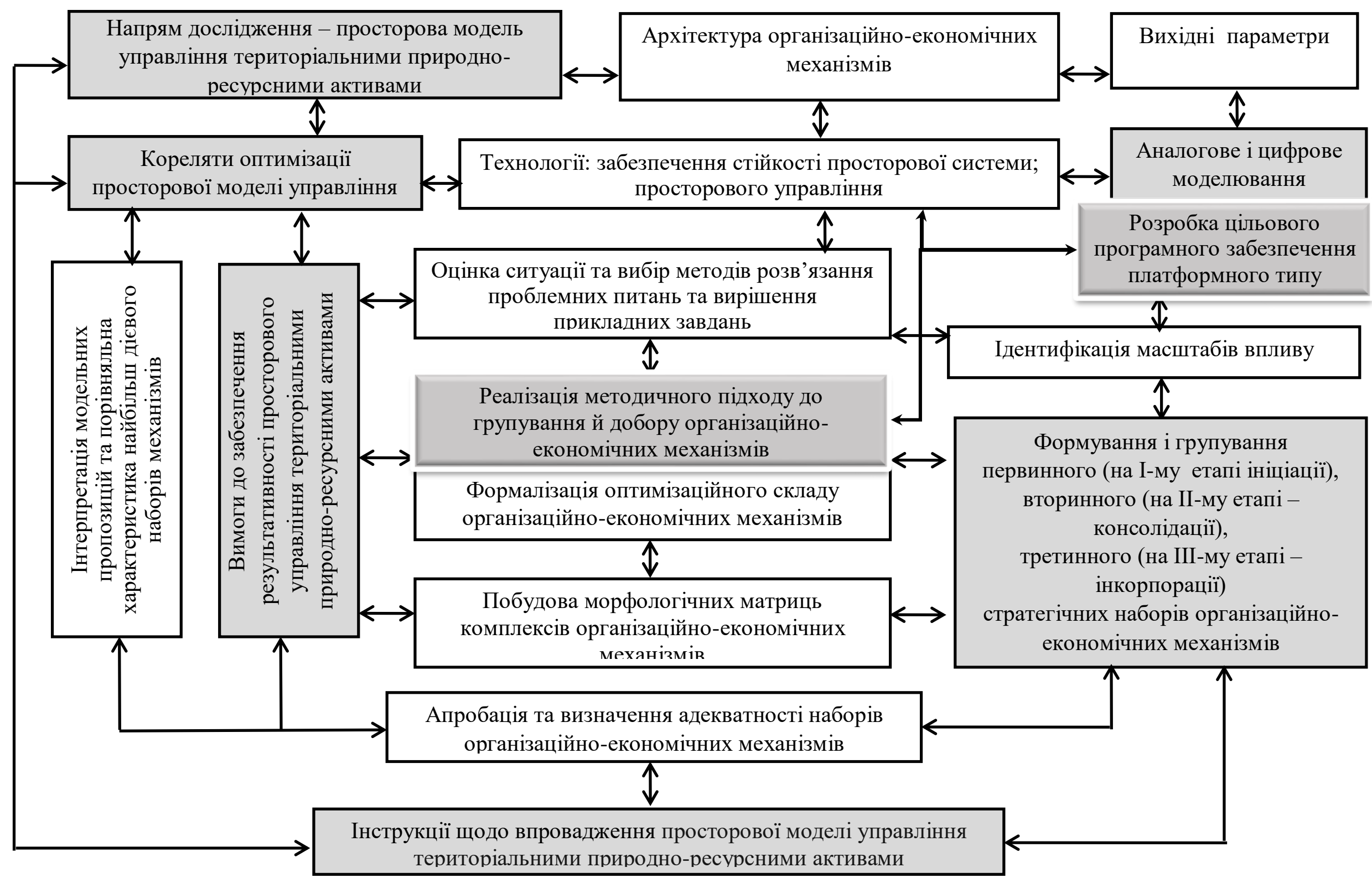

() Микитен

Рис.2. Структурно-логічна схема групування організаційно-економічних механізмів реалізації інтегральної просторової моделі управління територіальними природно-ресурсними активами (ПМУ ТпРА) 
статистичними, логістичними, атрибутивними та вторинними згрупуваннями, i процедур із урахування особливостей розроблення, формування і застосування певної природи важелів, і не лише на I-му та IIму етапах (ініціації та консолідації), а й на етапі III (інкорпорації) - методів згрупування організаційних відзнак, які дозволять встановити достатньо повний список важелів і регуляторів ${ }^{1}$.

Саме створений комплекс регулятивів i убезпечить: перманентне коригування цілей та завдань, уточнення пріоритетів на певний період упередження 3 урахуванням накопичених i набутих територіями та територіальними природно-господарськими утвореннями держави, загалом, масштабів потенціалу сталого розвитку, а також рівнів агресивності викликів, загроз і ризиків різного рівня й природи.

Відтак, розроблений й обгрунтований замкнений алгоритм (див., на рис. 3) методичного підходу до групування організаційно-економічних механізмів, за результатами врахування особливостей розмежування визначеної природи важелів та регуляторів за трьома етапами імплементації інтегральної просторової моделі: а) має замкнену природу 3 постійним підвищенням вимог до результативності добору і групування найбільш дієвих важелів та регуляторів; б) використовує мультидисциплінарний апарат; в) поєднує у собі різні процедури та методи ідентифікації, оцінювання і моделювання динамічних та статичних систем (економетричні, кваліметричні, логічного проектування, геометричної економетрики тощо).

Приведені автором розробки та обгрунтування дали змогу сформувати, розмежувати та структурувати комплекси організаційно-

${ }^{1}$ Що, само по собі й відтворюватиме варіативність і здатність до адаптивності та результативних трансформацій загального механізму просторового управління природно-ресурсними активами як держави, так і регіонів, територіальних округів, об’єднаних територіальних громад і інших мікро- територіальних об’єктів.

(C) Микитенко Вікторія 


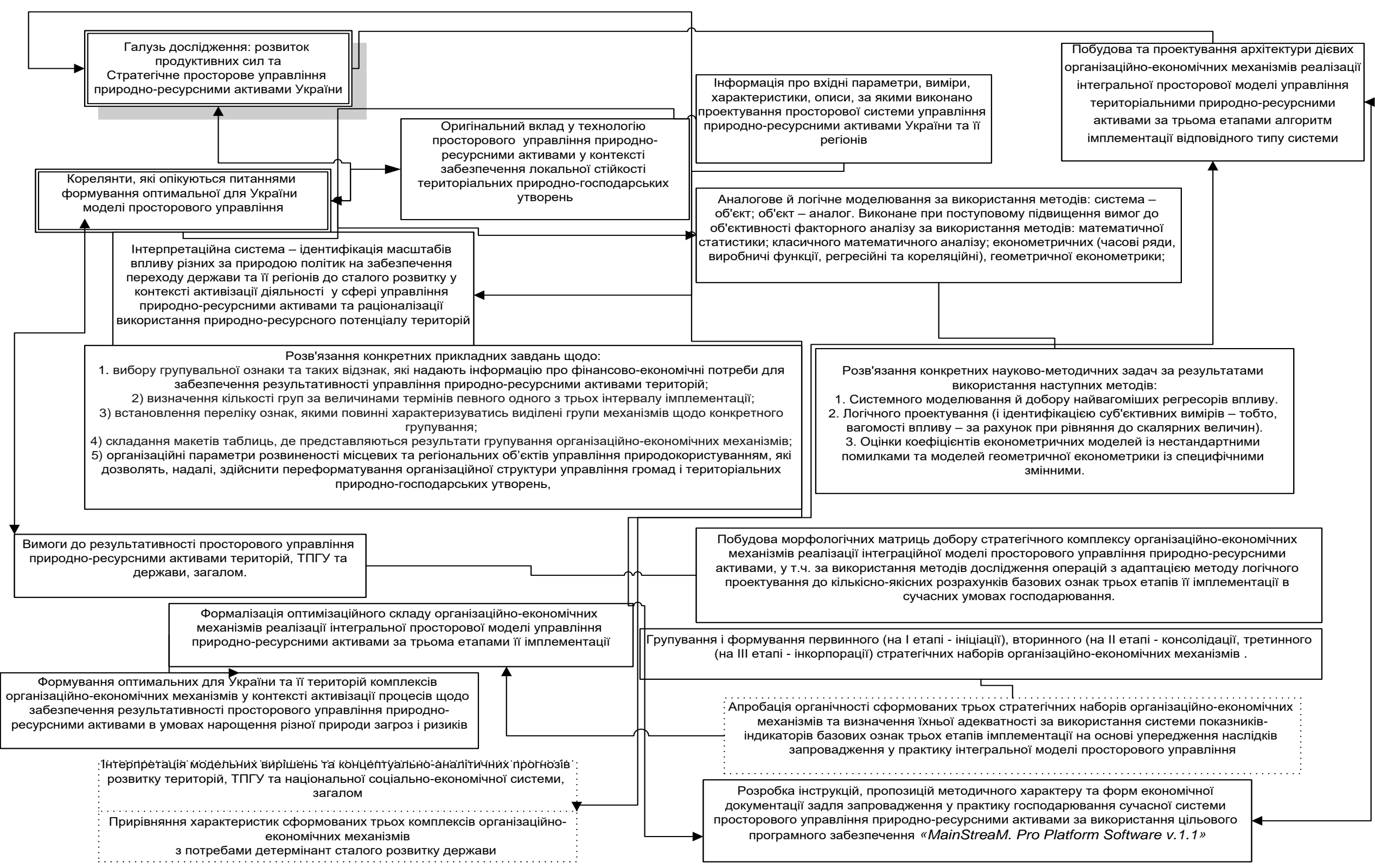

Рис. 3. Замкнена схема реалізації методичного підходу до групування організаційно-економічних механізмів реалізації інтегральної просторової моделі управління територіальними природно-ресурсними активами

() Микитенко Вікторія 
економічних механізмів реалізації дії за трьома етапами (ініціація, консолідація, інкорпорація) імплементації інтегральної просторової моделі управління територіальними природно-ресурсними активами в Україні, до складу яких входять фінансово-економічні, нормативно-правові, інформаційно-методичні, системно-універсальні та публічно-приватного партнерства підмеханізми, які забезпечують синхронний перебіг параболічних подій із інтенсифікації процесів видобутку, освоєння, використання i нарощення природно-ресурсного потенціалу територій, раціоналізації обміну перерозподілу природно-ресурсних активів територіальних природно-господарських округів та досягнення результативності просторового управління за рахунок конституювання i введення у практику складно організованої інтегральної просторової моделі управління територіальними природно-ресурсними активами держави.

Висновки. У цій відповідності, визнаємо, що інформаційнометодичні важелі задля узгодження стратегічного та поточного планування шляхом застосування єдиних методичних підходів і стандартів, а також і аналітичних процедур, які запропоновано у статті та опрацьовано за єдиним критерієм оцінювання-прогнозування результативності просторового управління природно-ресурсними активами, в межах організаційно-економічних механізмів реалізації інтегральної просторової моделі управління територіальними природно-ресурсними активами, мають бути прерогативою держави, промислових і аграрних корпорацій та інших суб’ єктів господарювання різного рівня, що визначує їх як один із ключових напрямів національної політики інформатизації в умовах постійного нарощення загроз і ризиків різної природи. Серед найбільш важливих питань у цій площині визначаємо проблему щодо забезпечення необхідною інформаційно-методичною базою суб’єктів управління усіх п’яти рівнів, які опікуються вказаною проблематикою та приймають 
управлінські рішення задля убезпечення варіативного інтегрального просторового управління природно-ресурсними активами територій. Оскільки, саме підвищення ступеня об'єктивності й ефективності інформаційно-методичного забезпечення стає, наразі, найвагомішим чинником досягнення ефективності просторового управління в умовах суспільно-політичної та економічної кризи i визначальних загроз національній безпеці.

\section{СПИСОК ВИКОРИСТАНИХ ДЖЕРЕЛ}

1. Каскади регіональних соціально-економічних систем: формування та розвиток: Монографія. / [О. М.Алимов, О. О. Демешок, І. В. Драган та ін.]. - Київ: ДУ «Інститут економіки природокористування та сталого розвитку НАН України», 2016. - 278 с.

2. Потенціал сталого розвитку України на шляху реалізації інтеграційного вибору держави: Монографія. / [О. М.Алимов, І. В. Драган, I. C. Ладонько та ін.]. - Київ: ДУ «Інститут економіки природокористування та сталого розвитку НАН України», 2014. - 520 с.

3. Формування системи механізмів управління природними ресурсами в умовах євроінтеграційних процесів / [І. К. Бистряков, Д. В. Клиновий, Н. В. Коржунова та ін.]. - Київ: ДУ «Інститут економіки природокористування та сталого розвитку НАН України», 2017. - 680 с.

4. Соціально-економічний потенціал сталого розвитку України та іiі регіонів / [О. М. Алимов, І. К. Бистряков, Е. М. Лібанова та ін.]. - Київ: ДУ «Інститут економіки природокористування та сталого розвитку НАН України», 2014. - 776 с.

5. Бистряков О. М. Переформатування просторової системи управління природно-ресурсними активами / О. М. Бистряков, В. В. Микитенко. // Економіка природокористування і сталий розвиток. - 2018. №2. - C. 234. 
6. Лицур I. М. Прогнозні можливості формування просторової системи управління природно-ресурсними активами. Історія народного господарства та економічної думки України: всеукраїнський історикоекономічний збірник наукових праць / I. М. Лицур, В. В. Микитенко. Київ: ДУ «Інститут економіки природокористування та сталого розвитку НАН України», 2018. - С.252-274.

7. Незалежна Україна в координатах сталого розвитку: Монографія. / [І. М. Крейдич, Д. О. Микитенко, В. В. Микитенко та ін.]. - Чернігів: Чернігівський національний технологічний університет, 2019. - 770 с.

8. Соціально-економічний потенціал сталого розвитку України та іii регіонів: вектори реального поступу: національна доповідь: Монографія. / [О. М. Алимов, О. І. Амоша, І. К. Бистряков та ін.]. - Київ: ДУ «Інститут економіки природокористування та сталого розвитку НАН України», 2017. $-865 \mathrm{c}$.

\section{REFERENCES:}

1. Alymov, O. M., Demeshok O. O., Dragan, I. V., \& Lytsur, I. M., et al. (2016). Kaskady rehionalnykh sotsialno-ekonomichnykh system: formuvannia ta rozvytok [Cascades regional socio-economic systems: the formation and development], Derzhavna ustanova «Instytut ekonomiky pryrodokorystuvannia ta staloho rozvytku», Kyiv [in Ukrainian].

2. Alymov, O. M., Demeshok, O. O., Drahan, I. V., \& Lytsur, I. M., et al. (2014). Potentsial staloho rozvytku Ukrainy na shliakhu realizatsii intehratsijnoho vyboru derzhavy [Potential of steady development of Ukraine is on the way of realization of integration choice of the state], DU «Instytut ekonomiky pryrodokorystuvannia ta staloho rozvytku NAN Ukrainy», Kyiv [in Ukrainian].

3. Bystriakov, I. K., Klynovyj, D. M., Korzhunova, N. V., Lytsur, I. M., \& Khvesyk, M. A. et al. (2017). Formuvannia systemy mekhanizmiv upravlinnia 
pryrodnymy resursamy $v$ umovakh ievrointehratsijnykh protsesiv [Formation of a system of mechanisms for managing natural resources in the context of European integration processes]. Kyiv: Public Institution "Institute of Environmental Economics and Sustainable Development of the National Academy of Sciences of Ukraine" [in Ukrainian].

4. Alymov, O. M., Bystriakov, I. K., Libanova, E. M., Lytsur, I. V., \& Khvesyk, M. A. et al. (2014). Sotsialno-ekonomichnyj potentsial staloho rozvytku Ukrainy ta ii rehioniv: natsionalna dopovid [Socio-economic potential of sustainable development of Ukraine and its regions: national report], DU Instytut ekonomiky pryrodokorystuvannia ta staloho rozvytku NAN Ukrainy, Kyiv [in Ukrainian].

5. Bystriakov, I. K., Mykytenko, V. V. (2018). "Reformatting of the spatial system of management of natural resource assets." Ekonomika pryrodokorystuvannia i stalyj rozvytok, vol. 1-2 (20-21). - 234 p. [in Ukrainian].

6. Lytsur, I. M., Mykytenko, V. V. (2018). "Predictive possibilities of formation of spatial system of management of natural resource assets." Istoriia narodnoho hospodarstva ta ekonomichnoi dumky Ukrainy: vseukrainskyj istoryko-ekonomichnyj zbirnyk naukovykh prats .- vol. 51. pp. 252-274 [in Ukrainian].

7. Krejdych, I.M., Mykytenko, D.O., Mykytenko, V.V., Shkarlet, S.M., \& Khudolej, V.Yu. et al. (2019). Nezalezhna Ukraina v koordynatakh staloho rozvytku (2nd ed.) [Independent Ukraine in the coordinates of sustainable development]. Chernihiv: Chernihiv National Technological University [in Ukrainian].

8. Alymov, O. M., Amosba, O. I., Bystriakov, I. K., Libanova, E. M., Mykytenko, V. V., \& Khvesyk, M. A. et al. (2017). Sotsialno-ekonomichnyj potentsial staloho rozvytku Ukrainy ta ii rehioniv: natsionalna dopovid: vektory realnoho postupu [Socio-economic potential of sustainable development of Ukraine and its regions: vectors of real progress: national report], DU Instytut 
ekonomiky pryrodokorystuvannia ta staloho rozvytku NAN Ukrainy, Kyiv [in Ukrainian].

Стаття надійшла до редакиії 14.04.2020

(C) Микитенко Вікторія 